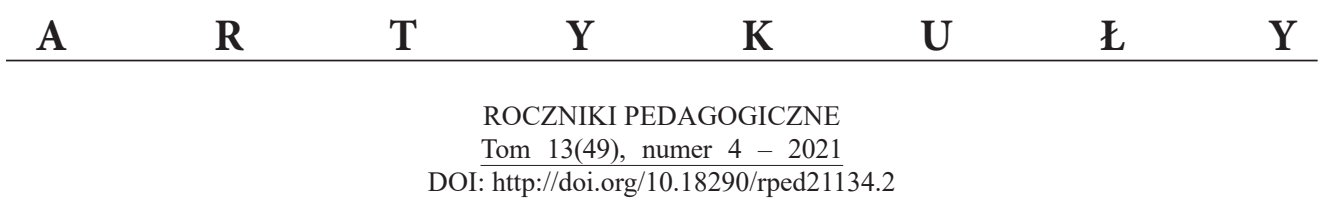

JAN KOCHEL

\title{
DZIECKO W PEDAGOGII BIBLIJNEJ
}

Pedagogika jest terminem wieloznacznym wywodzącym się z języka i kultury helleńskiej oraz środowiska grecko-rzymskiego. Źródłosłowem tego terminu jest grecki rzeczownik pais, którym określano dziecko - chłopca lub dziewczynkę wymagające całokształtu działań wychowawczych (gr. paideia) ze strony dorosłego wychowawcy (gr. paidagogos). W języku biblijnym słowo to oznaczało również sługę i niewolnika (doradcę) urzędnika królewskiego (Strong, 2015, s. 572-574). Biblijna pedagogia każe nam spoglądać na dziecko jako na dar, którego nie można odrzucić, lecz przyjąć z radością. W znaczeniu biblijnym dziecko jest bowiem owocem błogosławieństwa Stwórcy: „I błogosławił (hebr. brk) im [mężczyźnie i kobiecie], mówiąc: «Bądźcie płodni, mnóżcie się i zaludniajcie ziemię oraz czyńcie ją sobie poddaną...»" (Rdz 1,28). Przez błogosławieństwo nawiązuje się relację osobową między Bogiem i człowiekiem, a starożytny gest brania noworodka na kolana (w celu pobłogosławienia) oznacza przyjęcie dziecka do wspólnoty - do rodziny (por. Rdz 30,3; 48,9-12; Hi 3,12). Synonimem błogostawieństwa jest szeroko rozumiane „dobro” (Iz 65,8), które na pierwszym miejscu oznacza płodność i liczne potomstwo (Rdz 12,2; 13,16; 15,5; 16,10; Ps 107,38; $1 \mathrm{Sm} 2,20$ ), a zarazem konkretne profity materialne, komfort i prestiż w relacji z innymi (Lemański, 2013, 170n). Biblijny i pozabiblijny pajdocentryzm (terminu „pajdocentryzm” używamy w znaczeniu etymologicznym, a nie jako kierunku pedagogicznego) rzeczywiście stawia dziecko w centrum wspólnoty rodzinnej i całej społeczności ludzkiej (Jundziołł, Żołądź-Strzelczyk, 2002). Z tych wzglę-

Prof dr hab. JAN KocheL - Instytut Nauk Teologicznych, Wydział Teologiczny Uniwersytetu Opolskiego; adres do korespondencji: ul. Drzymały la, 45-342 Opole; e-mail: jkochel@uni.opole.pl; ORCID: https://orcid.org/0000-0002-0399-6056 
dów wywodzi się jednoznaczne potępienie wszelkich praktyk, które odrzucają, negują lub eliminują ten tak cenny dar, owoc błogosławieństwa.

\title{
1. DZIECKO - DAR I BŁOGOSŁAWIEŃSTWO
}

Jeśli dziecko jest cennym darem i owocem błogosławieństwa, to konsekwencją tego są wszelkie prawa, które mu przysługują. Z prawa naturalnego wynika tożsamość, godność i podmiotowość dziecka oraz pełny katalog jego praw i wolności (Konwencja o Prawach Dziecka, 1989). Z tego prawa pochodzą również inne regulacje prawne. Trafnie podkreślił tę wyjątkową wartość w kontekście dziecka kard. C.M. Martini (†2012):

\begin{abstract}
Dar [dziecko] nie jest nigdy czymś, co nam się prawnie należy i dlatego przyjmuje się go takim jakim on jest. Wynika stąd, że także niektóre sposoby mówienia o «prawie do dziecka», jakby to było coś, co należy się za wszelką cenę, niosą ze sobą niebezpieczeństwo uczynienia z dziecka jakiejś rzeczy, przedmiotu, i że przestanie się na nie patrzeć we właściwy sposób, jako na osobę i dar. Jeśli dziecko jest darem, to jesteśmy także powołani, aby przyjąć je takim, jakie zostało nam podarowane, nie określając go wcześniej przez uciekanie się do sposobów nie szanujących ludzkiego sensu aktu stwórczego. Argumenty te mogą stać się punktem wyjścia do podjęcia następnej krytyki, krytyki manipulacji genetycznej [...] ma on dzisiaj ogromne znaczenie dla moralności rodzinnej, społecznej, państwowej i politycznej (Martini, 1999, s. 37).
\end{abstract}

Akceptacja dziecka oraz jego prawa do życia i rozwoju wpływa na rozumienie dziecka jako „dobra”. W Księdze Rodzaju Stwórca określił wszystkie stworzenia jako „bardzo dobre” (Rdz 1,31; por. Syr 39,33-35; 1 Tm 4,4). Ta intensyfikacja oceny (dobry - bardzo dobry) nie dotyczy tutaj człowieka. Stopniowy rozwój rozumienia historii biblijnej (historii zbawienia) ujawni jednak w pełni kim jest człowiek: a) że został stworzony „na obraz Boży”; b) że w swej naturze jednoczy świat duchowy i świat materialny; c) że jest stworzony jako „mężczyzna i kobieta"; d) że Bóg obdarzył go swoją przyjaźnią (KKK 355-384), stąd określany jest jako „korona (szczyt) stworzenia” (Rdz 1,26; Ps 8,4-9) (Dokument PKB, 2020, s. 41-57).

Biblia mówi o dziecku nie tylko jako o niemowlęciu już narodzonym, ale wspomina o nim już w „łonie matki”, a więc w okresie prenatalnym (por. Rdz 25,22-24; 30,22; 49,25; Lb 3,12; 11,12; Pwt 28,4.57; Sdz 16,17; Rt 1,11; 1 Krl 17,19; Tb 4,4; 2 Mch 7,22.27; Hi 1,21; 31,15.18; Ps 22,11; 71,6; 127,3; 139,13-15; Prz 31,2; Koh 11,5; Mdr 7,1; Iz 49,1; 66,9; Jr 1,5; 20,17; Mt 19,12; Łk 1,15.41-44; 2,21; 11,27; $\mathrm{J} 3,4 ; \mathrm{Ga} 1,15)$. Hagiograf mierzy się zatem również z tematem statusu dziecka 
(nie)narodzonego (Lemański, 2014; por. Jan Paweł II Evangelium vitae, nr 2-6. 52-55; Franciszek, Evangelii gaudium, nr 213).

Termin „dziecko” w Starym Testamencie integralnie powiązany jest z wychowawczą troską rodziców i nauczycieli. Grecy używali kilku słów na określenie wychowawczej troski nad dzieckiem, np. paideia (od paideuō) jako „całokształt działań wychowawczych i tych związanych z kształceniem dzieci, jak i korygowaniem ich błędów - karceniem, ćwiczeniem, napominaniem; Dz 7,22; Ef 6,4; $2 \mathrm{Tm}$ 3,16; Hbr 12,5.7n.11; Ap 3,19), a także trefè (od threfō - ,żywić, utrzymywać, pielęgnować, dobrze kogoś chować" (Mt 6,26; Łk 4,16; 23,29) (Strong, 2015, s. 572. 776). Ojciec zwracał się do syna beni (bar) - „mój synu” (popularny element wielu imion patronimicznych, np. Ben-Churi, Benajasz, Beniamin lub Barabasz, Barnaba, Bartłomiej, Bartymeusz), a do córki (bat). Osiem dni po narodzeniu dziecka (chłopca) należało dopełnić rytuału, który składał się z trzech części: obrzezania, nadania imienia oraz przyjęcia noworodka do rodziny. Ojciec tuż po narodzinach sadzał dziecko na swe kolana i tym symbolicznym gestem uznawał je za swoje. Dzieci są równe wobec prawa Bożego bez względu na pochodzenie, płeć, narodowość, itd. Biblia wyróżnia też chłopca (na ar) na etapie dorastania, potrzebującego troski, czuwania i ochrony oraz peti - w sensie młodzieńca naiwnego, prostodusznego, łatwowiernego, niedoświadczonego, któremu brak mądrości (Prz 21,11; Ps 19,7[8]) czy rozeznania (Prz 9,6; Ps 119,130). Nie brak mu jednak dobrej woli, by się uczyć i dać się wychować (Prz 19,25; 21,11) (Bagrowicz, Jankowski, 2005, s. 37).

W zbiorze natchnionych pism Starego Testamentu wyróżnia się dwa pięcioksięgi (łac. pentateuchus), a w nich dwie wyjątkowe księgi dydaktyczne: Księgę Powtórzonego Prawa i Księgę Przysłów, które podkreślają wartość edukacyjną Biblii (Ravasi, 2002, s. 33-39). Drogę wychowawczą - biblijną zasadę edukacyjną - trafnie oddaje końcowy hymn Mojżesza z Księgi Powtórzonego Prawa, który skupia - jak w soczewce - całą ,pedagogię Bożą”. W poemacie tym na szczególną uwagę zasługują dwie metafory, podkreślające rodzicielską (ojcowska i macierzyńska) troskę i czułość Boga oraz specyficzną metodę nauczania i wychowywania ludu:

Znalazł go [lud] na ziemi pustynnej, na pustkowiu, gdzie rozległy się dzikie głosy.

Otoczył go troskliwą opieką

i strzegł jak źrenicy oka.

Jak orzeł, który budzi swe gniazdo

i krąży nad pisklętami, 
a gdy rozłoży swoje skrzydła, bierze je na siebie i unosi tak Pan sam go prowadzi, a nie było z Nim obcego boga (Pwt 32,10-12).

Bóg, wychowujący swój lud, przypomina orła, który strzeże swe pisklęta, dba o nie, jest wrażliwy na każde niebezpieczeństwo („źrenica oka”), lecz równocześnie nie zapomina o ćwiczeniu i kształtowaniu umiejętności latania („bierze je na siebie i unosi"). Jest to obraz Boga, który strzeże, żywi, opiekuje się, naucza i wychowuje - wymaga i ćwiczy (Martini, 1987; Szwarc, 2000; Pawlaczyk, 2013; Belleil, 2016).

Biblijną zasadę edukacyjną trafnie oddaje też autor Księgi Przysłów, który rozpoczyna zbiór przysłów/przypowieści (hebr. meszalim - „pouczenia religijne bądź moralne") od określenia celu wychowania:

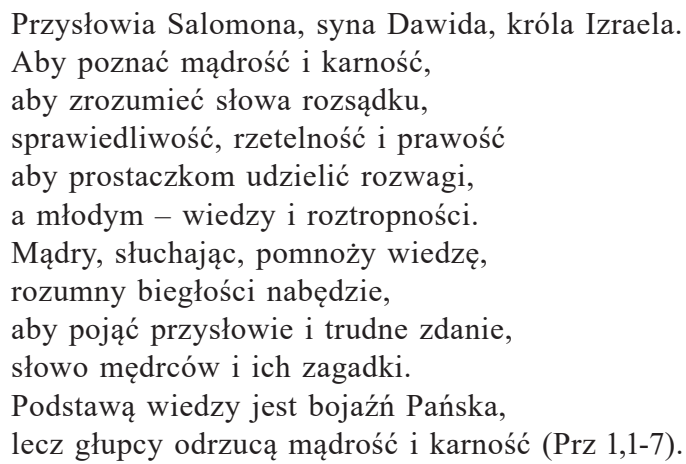

Celem pouczenia jest nie tyle wiedza, co nabycie mądrości i karności. Podstawą programową edukacji - początkiem, punktem centralnym, najważniejszym czynnikiem mądrości - jest „bojaźń Boża”, czyli szacunek i posłuszeństwo względem Boskiego Wychowawcy (Pinto, 2006). Autor wyróżnia prostaczków/ niedoświadczonych (dzieci) oraz młodych/nastolatków (młodzież), którzy pod wpływem nauczania i wychowania nabywają rozwagi, wiedzy i zdolności (umiejętności) (Signoretto, 2006; Potocki, 1988; Nawrot, 2008; Kułaczkowski, 2002; Chrostowski, 2010).

W Nowym Testamencie termin „dziecko” pojawia się w cieniu istotnych wydarzeń zbawczych, ale nie jest ono pozbawione troski i opieki ze strony rodziców (Wojciechowska, 2015). Pierwszy raz mowa o dzieciach w kontekście narodzenia i dzieciństwa Jezusa w okolicach Betlejem. Herod wysyła swoich żołnierzy, by dokonali eksterminacji „wszystkich chłopców poniżej dwóch lat” (Mt 2,16). Ewangelista przywołuje - jako komentarz - fragment z proroka Jeremiasza: 
„Rachel opłakuje swoje dzieci i nie chce, by ją pocieszono, bo ich już nie ma” (Jr 31,15). Nie po raz pierwszy niewinne dzieci stają się ofiarami gry interesów władców tego świata.

Kolejny raz dzieci są bohaterami publicznego nauczania Mistrza z Nazaretu, zwłaszcza przypowieści i opisów uzdrowień, np. syna setnika z Kafarnaum (por. Mk 1,40-44; Mt 8,5-13; Łk 5,12-14). W tej osadzie rybackiej, w której zbiegały się różne szlaki handlowe, stacjonował spory garnizon dowodzony przez setnika. Oficer był człowiekiem wrażliwym, przychylnym Żydom (zbudował im synagogę), ale też troskliwym panem (niewolnika) bądź ojcem (syna) (por. Łk 7,7). Osobiście prosi Jezusa o uzdrowienie chłopca, który „leży w domu sparaliżowany i bardzo cierpi” (Mt 8,6; por. J 4,43-53). Cierpiące dziecko zawsze budzi współczucie i chęć pomocy (działania). Istotną rolę w tym wydarzeniu odgrywa wiara opiekuna (ojca). W tym kontekście analogię stanowi troska matki, poganki z okolic Tyru i Sydonu (Syrofenicjanki), która „walczy” o swoją córeczkę „opętaną przez ducha nieczystego" (Mk 7,24-30). Jezus docenia też jej determinację i zdumiewa się jej wiarą: „Kiedy wróciła do domu, znalazła dziecko leżące na łóżku, a demon odszedł" (Mk 7,30; por. Mt 17,18; Łk 8,49-56).

Mało kto dostrzega obecność chłopca (gr. paidárion - „chłopczyk, chłopiec”) w Janowym opisie rozmnożenia chleba (J 6,9; por. Mk 6,30-44; 8,1-10; Mt 14,13-21; 15,32-39; Łk 9,10-17). To jedyne miejscu w NT, w którym pojawia się ten termin. Wzmianka o chłopcu z pięcioma chlebami jęczmiennymi i dwiema rybami jest epizodem, ale pokazuje, że "materię dla Jezusowego cudu dostarcza dziecko". James Martin SJ - amerykański kierownik duchowy, dziennikarz i pisarz katolicki - w związku z tym zauważa, że „może Bóg uczynić coś wielkiego z czegoś małego" (Martin, 2017, s. 298). Zapowiedź cudu eucharystycznego jest (jeśli nie liczyć Zmartwychwstania) zapisana we wszystkich czterech Ewangeliach, ale wzmianka o dziecku pojawia się tylko w czwartej Ewangelii. Dziecko jest jednak obecne w najważniejszych wydarzeniach historii zbawienia.

Charakterystyczne jest również to, że Jezus utożsamia się z dzieckiem - małym, niewinnym, prostym. Najpierw przywołuje proroka Izajasza i utożsamia siebie ze Sługą umiłowanym Ojca (Mt 12,18; por. Mt 17,5; Łk 9,35; Dz 3,26), a później wszystkim swoim uczniom każe stawać się podobnymi do dzieci: „Jeśli się nie odmienicie i nie staniecie jak dzieci, nie wejdziecie do królestwa niebieskiego" (Mt 18,3 BT; por. Mk 9,37; 10,15; Łk 9,47-48; 18,17) (Malina, 2013; Linke, 2013; Wons, 2013; Pikor, 2017). Istotne jest to, że żaden z synoptyków nie pominął tego wyzwania.

Obraz „dziecka” służy wreszcie Jezusowi do wyjaśnienia uczniom, jaka postawa jest konieczna, aby stać się członkiem królestwa Bożego, czyli zaakceptować panowanie Bożego prawa i kultury życia. W pouczeniach i metaforach Mistrza 
z Nazaretu dzieci są zawsze w towarzystwie jakichś opiekunów - rodziców, wychowawców, przełożonych. W ten sposób podkreślona zostaje prawda, że dziecko nie jest w stanie samo zatroszczyć się o siebie. Nie można zostawić je samemu sobie, a tym samym wystawić na zgubne działanie różnych złych wpływów i złych ludzi. Dorosły, rodzic, nauczyciel czy wychowawca jest wezwany, by zatroszczyć się o tych małych, słabych i ostatnich, inaczej ,nie [wejdzie] do królestwa niebieskiego" (Mt 18,3; por. Mk 10,15; Łk 18,17).

Ewangeliczne opowiadanie o spotkaniu i błogosławieństwie dzieci potwierdza istotny element pedagogii Jezusa (por. Ct 7-9). Dziecko jest w niej obecne, nie jest marginalizowane. Oczywiście nie znajduje się w centrum nauczania, ale według Jezusa nie może być pozbawione pełnej inicjacji, nauczania i wychowania w wierze. To jest zadanie rodziców i wychowawców. Jednoznaczny nakaz: „Dopuście dzieci! Nie przeszkadzajcie im przyjść do Mnie, bo do takich należy królestwo niebieskie" (Mt 19,14; por. Mk 10,13-16; Łk 18,15-17), świadczy o pełni praw dziecka do integralnego wychowania chrześcijańskiego (por. DWCH 1-2). Pedagogia Jezusa podkreśla, że dzieci wymagają nie tylko wychowawczej troski (Łk 2,41-52), ale również czułości i miłości bezwarunkowej, niezależnie od dziecięcego zachowania (Ratzinger-Benedykt XVI, 2012, s. 161-169; Martin 2017, s. 87-114). Jezus jako Nauczyciel jest wzorem dla wszystkich nauczycieli i wychowawców, ponieważ „wewnętrzna spójność i siła przekonująca Jego nauki płynie stąd, że Jego słowa, przypowieści i rozprawy nie dają się nigdy oddzielić od Jego życia i Osoby" (Ct 8). Takiej wewnętrznej harmonii domagają się działania wychowawcze wszystkich pedagogów dziecięcych.

\section{CELE I ZADANIA PAJDOCENTRYZMU BIBLIJNEGO}

Pajdocentryzm to nurt pedagogiczny, zgodnie z którym dziecku przyznaje się centralną pozycję $\mathrm{w}$ procesie nauczania $\mathrm{i}$ wychowania. W Biblii dziecko nie jest eksponowane, ale potwierdza się w niej niezaprzeczalną godność dziecka i jego wrodzone możliwości intelektualne (por. Rdz 1,26; Prz 9,9; 20,11; KKK 1700-1709; KDK 22). Pedagogika dziecka przyjmuje jako główny cel rozwój indywidualnych predyspozycji, zainteresowań i potrzeb najmłodszych; korzeniami sięga do pedagogiki naturalistycznej, utożsamiającej proces wychowania z dostosowaniem się wychowawcy do naturalnego, spontanicznego rozwoju wychowanka. Oczywiście może budzić obawy nurt, który traktuje wychowanie jako samą tylko opiekę nad samorzutnym rozwojem dziecka, do którego należy dostosować programy, metody i organizację pracy wychowawczo-dydaktycznej, a wyraźnie nie doceniać roli nauczyciela i społeczno-kulturowych uwarunkowań edukacji (Okoń, 2004, s. 293; 
Dobrołowicz, 2005, s. 8-10; Śliwerski, 2007). Pedagogia biblijna szanuje tradycyjne ujęcie roli rodziców i nauczycieli w procesie wychowania. W pierwszym przypadku wiąże się to z IV przykazaniem Bożym (Filipiak, 1981,; Carrón, 1996; Olbrycht, 2014; Gądecki, 2015), a w drugim - rodzic/nauczyciel jest autorytetem nie podlegającym dyskusji (Wronka, 2013). Rodzice odgrywają wobec dziecka rolę fundamentalną, mają więc prawo do kierowania ich życiem (Wj 21,7), ale mają też obowiązek opiekowania się nim i wychowywania, także pod względem religijnym (Pwt 4,9). Idee tego typu wychowania mają zdrowe podstawy, kiedy opierają się na pedagogice personalistyczno-egzystencjalnej (Kunowski, 2000; Adamski, 2005; Kiereś, 2009; Tarnowski, 1982; 1993).

Bazą tego typu pedagogiki jest „pedagogia Boża”, źródło i wzór pedagogiki wiary (por. DOK 139-147). „Bóg obchodzi się z wami jak z dziećmi” - przekonuje autor Listu do Hebrajczyków (Hbr 12,7). Pedagogia biblijna ukazuje Boga jako miłosiernego ojca, nauczyciela i mędrca (por. Pwt 8,5; Oz 11,3-4; Prz 3,11-12). On jest Wychowawcą swojego ludu - wychowuje poprzez prawo, wydarzenia, pisma (por. Ps 94,12; Syr 32,14; 1 Kor 4,15; Ga 3,24n) (Martini, 1987). W tym modelu wychowania każdy człowiek, w tym dziecko, przyjmowany jest „w takiej kondycji, w jakiej się znajduje, wyzwala go z więzów zła, przyciąga do siebie więzami miłości, pomaga mu wzrastać w sposób stopniowy i cierpliwy do dojrzałości wolnego syna, wiernego i posłusznego Jego słowu [...] upomina przez przekazywanie nagrody i kary, formuje przez próby i cierpienia" (DOK 139). Istotna jest więc ciągłość tradycji wychowawczej i konsekwencja w procesie edukacyjnym. Celem zaś wychowania w wierze jest doprowadzenie ucznia do spotkania i zażyłej przyjaźni z Jezusem Jedynym Nauczycielem, Panem i Mistrzem (Mt 23,8. 10; J 3,2; 13,13-14; por. Ct 5. 20; DOK 140; DK 157-163).

$\mathrm{W}$ tradycyjnym ujęciu pedagogia dziecka nabiera cech pedagogiki personalistyczno-egzystencjalnej, w której wyróżnia się następujące zadania wychowawców:

- przekazywanie wiedzy antropologicznej, etycznej i pedagogicznej dotyczącej rozwoju osoby (Kim jest człowiek? Jaką wartość stanowi to, że jest on osobą? Jaki jest cel życia? Jakie ma możliwości i zobowiązania względem siebie i innych?);

- stworzenie warunków i sytuacji wychowawczych zachęcających do pracy nad sobą, wskazanie możliwości i sposobów doskonalenia się (kształcenie cnót, charakteru, umiejętności), stawianie jasnych wymagań i osobistego świadectwa wierności głoszonym zasadom;

- wprowadzenie w proces wychowania sytuacji i działań z innymi i dla innych, troski o dobro wspólne, kształtowanie postawy miłości (rozumianej jako gotowość do świadomego bycia dobrowolnym darem dla drugiego), bezinteresowności, uczenie postawy służby dla innych (Smołka, 2011, kol. 342n). 
W Piśmie Świętym nie brak elementów integralnej pedagogiki dziecka (Harrison, 1997; Guzewicz, 2010; Dobrzański, 2017; Haręzga, 2017). Dlatego w oparciu o wybrane fragmenty można wyróżnić kilka zasad wychowania:

- dziecko pozostaje w centrum pedagogiki jako podmiot (osoba) - „obraz żyjącego Boga” (Rdz 1,26-27; 5,1), „ukoronowany chwałą i czcią” (godność) (Ps 8,4-9) i „otwarte” na Boga (capax Dei) (istota religijna) (KKK 27-30) (Kochel, 2018, s. 13-20);

- dziecko jest zobowiązane do okazywania szacunku i posłuszeństwa rodzicom (por. Wj 20,12; Pwt 5,16; Prz 1,8; 6,20; 19,26n; 20,20; 28,7; 30,11.17; Syr 3,1-16; 7,27-28; 30,2; Mt 15,4; Ef 6,1-3) (Kołaczkowski, 2009);

- dzieci domagają się również prawdziwej służebnej miłości i odpowiedzialnej troski ze strony rodziców (por. Mk 7,27; Ef 6,4) (Jankowiak, 2015);

- dzieci zobowiązane są do zachowania zasad życia rodzinnego według tzw. „kodeksów/tablic domowych” (por. Ef 5,1-5; Kol 3,20-25; Tt 2,1-10) (Sikora, 1995);

- dom rodzinny pozostaje pierwszym i podstawowym środowiskiem wychowania dla dziecka (por. Ps 128; Łk 2,51; AL 8-30) (Tronina, 1995).

Pedagogika dziecka rzeczywiście odnajduje swoje źródło w Piśmie Świętym. Dziecku przyznaje się tam właściwe miejsce i podmiotową rolę. Biblia ma swoją wartość edukacyjną nie tylko z powodu jej walorów literackich czy historycznych, ale przede wszystkim dlatego, że jest „księgą Ducha Świętego, która porusza serce ku dobru i prawdzie. Opisuje ona warunki głębokiej autentyczności na ludzkiej drodze, stymuluje pozytywną energię, odsłania każdą zasadzkę i fałsz, które uniemożliwiają kroczenie na drodze świętości. Jest to księga edukacyjna również dlatego, ponieważ stawia Boga jako wychowawcę w centrum..." procesu wychowania (Ravasi, s. 35).

Jeśli Boski Wychowawca będzie w centrum edukacji, to i dziecko, jako Jego „obraz”, będzie zajmować centralne miejsce w procesie wychowania. Rodzice i wychowawcy, odkrywając swoje prawo i obowiązek do wychowania dzieci (por. DWCH 3), będą również dziecku przyznawać centralną pozycję i stawiać sobie jako główny cel rozwój indywidualnych predyspozycji, zainteresowań i potrzeb dziecka.

Gary Smalley $(\dagger 2016)$ - amerykański pedagog i doradca rodzinny - trafnie zauważył: „Jednym z najważniejszych sposobów wyrażania naszym dzieciom miłości i wsparcia jest bezwarunkowe oddanie się im na całe życie. Osoba cechująca się takim oddaniem mówi: «Jesteś dla mnie ważny dzisiaj i jutro niezależnie od tego, co się stanie»" (Smalley, 2006, s. 42). 


\section{DZIECIĘCTWO DUCHOWE}

Na zakończenie jeszcze krótka refleksja o dziecięctwie Bożym - dziecięctwie duchowym. Dzięki wierze odkrywamy, że jesteśmy dziećmi Bożymi i dzięki Bogu stajemy się silni i wolni (por. Ga 5,1.22; Ef 5,8). Język biblijny często nie używając bezpośrednio pojęcia „wolność” opisuje wewnętrzną postawę, która ją wyraża, np. powtarzając wezwanie:

Szukajcie Pana, wy wszyscy pokorni ziemi, którzy wypełniacie Jego nakaz; szukajcie sprawiedliwości, szukajcie pokory, może się ukryjecie w dzień gniewu Pańskiego (So 2,3; por. Am 5,4; Iz 57,15).

Ten, kto czuje się zewnętrznie opuszczony i uciśniony, pokłada całą swoją ufność w Bogu, zawierza się Ojcu, Jemu powierza swoje plany i dlatego czuje się naprawdę wolny i kochany. Biblijni „pokorni ziemi” lub „ubodzy” zajmują w Biblii ważne miejsce, są też kojarzeni z dziećmi - małymi, pokornymi, bezbronnymi. Prorok Sofoniasz nadaje tej kategorii ludzi nowe znaczenie o odcieniu moralnym i eschatologicznym $(3,11)$. W komentarzu do Biblii Jerozolimskiej czytamy: „W epoce Septuaginty termin ‘anaw (lub `aní) coraz bardziej wyraża ideę altruizmu (Za 9,9; por. Syr 1,27). To do «ubogich» zostanie posłany Mesjasz (Iz 61,1; por. Iz 11,4; Ps 72,12n; Łk 4,18). On sam będzie pokorny i łagodny (Za 9,9; por. Mt 11,29; 21,5), a nawet udręczony (Iz 53,4; Ps 22,25). Hebr. `anawím zapowiada ewangelicznych „ubogich [w duchu]” (gr. ptōchos - „ubogi, potrzebujący”; Mt 5,3; por. 11,5) (Kostecki, 2017). Zauważamy tu podobieństwo zachodzące pomiędzy językiem Starego Testamentu a Kazaniem na Górze i błogosławieństwem: „Szczęśliwi ubodzy w duchu, ponieważ do nich należy królestwo Boże” (Mt 5,3 BP); posiadają oni pełną i doskonałą wolność Królestwa, ponieważ należą całkowicie do Ojca - są dziećmi Bożymi.

Kard. Martini wyjaśnia:

Ubóstwo oznacza to samo, co dziecięctwo duchowe, które jest niezbędne, aby wejść do Królestwa. Wyrzekając się chęci posiadania i władzy, która czyni zawsze człowieka niewolnikiem idoli, doświadczamy wolności dziecka, to znaczny wolności tego, kto zawierzył Ojcu i wie, że otrzyma to wszystko, czego potrzebuje i dlatego porusza się on w pełnej wolności we własnym środowisku, także w sferze kultury, w sferze społecznej i politycznej. Nie wycofujemy się, nie stajemy z boku, lecz przezwyciężając dzięki łasce Ducha Świętego, strach przed utratą zaszczytów i powodzenia oraz niepokój o to, co inni sobie o nas pomyślą, poruszamy się w wolności, pokorze i świadomości dziecięctwa ewangelicznego (Martini, 1999, s. 39). 
Biblijna pedagogia dziecka - osoby wolnej i obdarzonej potencjałem zdolności i możliwości - pomaga odkryć nauczycielom i wychowawcom drogę doskonałości, przyjmując, że sam Bóg jest ojcem i wzorem w swojej zdolności kochania: „Bądźcie więc tak doskonali, jak doskonały jest wasz Ojciec Niebieski” (Mt 5,48 BP; por. Mt 19,21; 1 Kor 14,20; Kol 4,12; Jk 1,4).

Dziecięctwo Boże - podobieństwo do obrazu Boga, zapisane w akcie stworzenia (Rdz 1,26), „przedstawione jest tutaj nie jako fakt, ale jako obowiązek, apel wolności, a zatem [jego] realizacja powierzona jest ludzkiemu zaangażowaniu". Z drugiej strony ewangeliczny Mistrz z Nazaretu „przedstawia się jako postać, którą należy naśladować, zawsze na drodze miłości: «Uczcie się ode Mnie, bo jestem cichy i pokorny sercem» (Mt 11,29 BT); «daję wam przykład, abyście i wy czynili tak, jak Ja wam uczyniłem» (J 13,15 BT); «tak jak Ja was umiłowałem; żebyście i wy tak się miłowali wzajemnie» (J 13,34; 15,12) [...]. Podobni do człowieka ziemskiego, chrześcijanie są również podobni do Pana (1 Kor 15,49; 2 Kor 3,18)" (Dokument PKB, s. 56).

Dar dziecięca duchowego jest wyzwaniem dla każdego chrześcijanina, który zanim stał się rodzicem, nauczycielem czy wychowawcą był dzieckiem i uczniem. Ewangelista Mateusz przypomniał o tym w kontekście porównania do gospodarza domu, który „ze swego skarbca wyjmuje to, co nowe i stare” (Mt 13,52 BP). Podkreśla wymiar duchowy, kiedy wzywa do przemiany: nauczyciel winien stać się na nowo uczniem, gospodarz - ojcem, a sługa - dzieckiem. Tylko ten, kto staje się na nowo dzieckiem - małym, pokornym, ubogim, może wejść do królestwa Bożego: „Jeśli się nie odmienicie i nie staniecie jak dzieci, nie wejdziecie do królestwa niebieskiego" (Mt 18,3 BT). Prawdziwy uczeń Jezusa ma swój skarb w niebie (por. Mt 6,20; 19,21). Kto zatem chce rzeczywiście należeć do wspólnoty dzieci Bożych, musi zmienić swój sposób myślenia i swój styl życia na ewangeliczny i odrzucić wszelkie egoistyczne dążenia (por. Ef 4,21-24; Kol 3,9-10; Rz 8,14-17).

Stawiając dziecko w centrum procesów edukacyjnych naśladujemy Boga Wychowawcę, który wyraźnie nakazywał strzec i dbać o dzieci, chronić ich godności i podmiotowości, karmić i żywić, utrzymywać w karności i napominać, czyli dobrze nauczać i wychowywać. Podstawowym celem i zadaniem pedagogiki jest więc odpowiedzialna troska o każde dziecko, wzbogacona o empatię i wrażliwość, co prorok Ozeasz nazywa „podniesieniem do swego policzka” (Oz 11,4), Ewangelia „objęciem, błogosławieństwem i dotknięciem rąk” (Mk 10,16), a papież Franciszek „czułością przytulenia” (AL 27-30). 


\section{BIBLIOGRAFIA}

Adamski, F. (2005). Wychowanie personalistyczne. Wybór tekstów. Kraków: Wydawnictwo WAM. Bagrowicz, J. i Jankowski, S. (2005). „Pan, Bóg twój, wychowuje ciebie” (Pwt 8,5). Studia z pedagogii biblijnej. Toruń: Wydawnictwo Uniwersytetu M. Kopernika.

BelleIL, O. (2016). Być jak biblijny ojciec (tł. J. Wisła-Truty). Kraków: Wydawnictwo św. Stanisława BM.

Byrskog, S. (1994). Jesus the Only Teacher. Didactic Authority and transmission in Ancient Izrael. Stockholm: Ancient Judaism and the Matthean Community.

CARrón, J. (1996). Sens czwartego przykazania i historia jego interpretacji. ComP, 16(1), 3-19.

Chrostowski, W. (2010). „Kto wychowuje swego syna, będzie miał z niego pociechę” (Syr 30,2). Elementy wychowawcze w biblijnej literaturze międzytestamentalnej. W: J. BAGROwICZ i S. JANKOwSкI (red.). ,, Wy mnie nazywacie «Nauczycielem» $i$ «Panem» $i$ dobrze mówicie” (J 13,13). Wychowanie $w$ tradycji biblijnej późnożydowskiej $i$ wczesnochrześcijańskiej (s. 51-70). Toruń: Wydawnictwo Naukowe UMK 2010.

Dobrolowicz, J. (2005). Pajdocentryzm. W: T. Plich (red.). Encyklopedia pedagogiczna XXI wieku, t. IV (s. 8-10). Warszawa: Wydawnictwo Akademickie ŻAK.

DobrZański, A. (2017). Od Ewangelii dziecka do Ewangelii życia. Pastores, 1, 137-144.

Dokument Papieskiej Komisji Biblijnej. (2020). Czym jest człowiek? Zarys antropologii biblijnej (tł. H. Witczyk). Lublin: Dzieło Biblijne im. Jana Pawła II.

FiLIPIAK, M. (1981). „Czcij ojca twego i matkę twoją”. RTK, 28(1), 5-12.

FranciszeK (2013). Adhortacja apostolska „Evangelii gaudium”. Kraków: Wydawnictwo M.

Fugate, J.R. (2008). Wychowanie dziecka wedtug Pisma Świętego (tł. M. Stiff, A. Gandecki). Lublin: Pojednanie.

GąDECKI, S. (2015). Dekalog IV. Przykazanie czwarte: Czcij twego ojca i twoją matkę. Miesięcznik Kościelny Archidiecezji Poznańskiej, 66(10), 589-610.

Guzewicz, M. (2010). Zasady wychowania w Piśmie Świętym. Studium teologiczno-pastoralne. Wrocław: Papieski Wydział Teologiczny.

Haręzga, S. (2017). Jezus i dzieci - nowość Ewangelii. Pastores, 1, 7-19.

Harrison, R. (1997). Biblijne zasady wychowania dzieci (tł. J. Pruszyński). Pszczyna: CEF Press.

Horns, C.B. i Martens, J.W. (2009). Let the Little Children Come to Me. Children and Childhood in Erly Christianity. Washington: Catholic University of America Press.

JAN PAWel II (1979). Adhortacja apostolska „Catechesi tradendae”. AAS, 71, 1277-1340.

JAN PAwEe II (1995). Encyklika „Evangelium vitae”. Watykan: Libreria Editrice Vaticana.

JANKowiak, J. (2015). Rola wychowawcza ojca według Ef 6,4. Labor et Educatio, 3, 51-65.

JundzilŁ, J. i ŻoŁĄDź-STRZELCZYK, D. (2002). Dziecko w rodzinie i społeczeństwie. Starożytność Średniowiecze, t. 1. Bydgoszcz: Wyd. Uczelniane Akademii Bydgoskiej im. Kazimierza Wielkiego.

Katechizm Kościoła Katolickiego (1994). Poznań: Pallottinum.

Kertelge, K. (2005). Ukryte życie Jezusa w świetle Ewangelii. Szkic egzegetyczny. ComP, 25 (1), 43-46.

Kiereś, B. (2009). O personalizmie w pedagogice. Studia i szkice z teorii wychowania. Lublin: Instytut Edukacji Narodowej. 
Kochel, J. (2021). Prymat rodziny w nauczaniu Jana Pawła II. W: Opuscula dedicata 14, Poznań: Wydawnictwo UAM.

Kochel, J. (2018). Wprowadzenie do antropologii pedagogicznej. W kregu pedagogiki katolickiej. Opole: Redakcja Wydawnictw WT UO.

Kochel, J. i Marek, Z. (2012). Pedagogia biblijna w katechezie. Kraków: Wydawnictwo WAM.

Kostecki, D. (2017). Aluzje do Księgi Sofoniasza w Nowym Testamencie? CTh, 87(4), 107-124.

Kongregacja ds. Duchowieństwa (1998). Dyrektorium ogólne o katechizacji. Poznań: Pallottinum.

Konwencja o Prawach Dziecka (1989). W: Dziennik Ustaw nr 120, poz. 526.

KuŁaczKowski, J. (2009). Wskazania wychowawcze dla dzieci w świetle Ef 6,1-4. Paedagogia Christiana 1(23), 177-190.

KuŁaczkowski, J. (2002). Znaczenie „bojaźni Jahwe” w formacji mądrościowej człowieka w ujęciu Księgi Przysłów. Zeszyty Naukowe KUL, 45(3-4), 3-19.

Kunowski, S. (2000). Problematyka wspótczesnych systemów wychowania. Kraków: Oficyna Wydawnicza Impuls.

Lemański, J. (2013). Księga Rodzaju - rozdziały 1-11 (NKB ST I/1). Częstochowa: Edycja św. Pawła.

Lemański, J. (2014). Pytanie o status (nie)narodzonego dziecka w Starym Testamencie. Wj 21,22-25 jako przypadek szczególny. Biblica et Patristica Thoruniensia, 7(3), 9-39.

Linke, W. (2013). Jak dorosły może stać się dzieckiem (Mt 18,3) lub narodzić się na nowo (J 3,3.5)? Katecheta, 57(11), 63-67.

ŁACH, J. (2002). Rodzina i jej powinności w pouczeniu Listu do Kolosan 3,18-4,6. W: E. Osewska, J. Stala (red.). Drogi katechezy rodzinnej (s. 169-180). Poznań: Wydawnictwo św. Wojciecha.

MalinA, A. (2013). Sens bycia dzieckiem (Mt 18,1-4). Verbum Vitae, 12(24), 97-116.

Martin, J. (2017). Jezus (tł. K. Jasiński, A. Wawrzyniak). Poznań: Wydawnictwo Św. Wojciecha.

Martini, C.M. (1999). Stownik duchowy. Mały przewodnik dla duszy (tł. H. Bzikot). Kraków: Wydawnictwo M.

Martini, C.M. (1987). Dio educa il suo popolo. Mialno: Centro Ambrosiano.

Nawrot, J. (2008). Ojcowskie pouczenie mądrościowe w Księdze Przysłów. Poznańskie Studia Teologiczne 22, 43-54.

OкоŃ, W. (2004). Nowy stownik pedagogiczny. Warszawa: Wydawnictwo Akademickie ŻAK.

Olbrycht, K. (2014). Obrona sensu IV przykazania Bożego - Czcij ojca swego i matkę swoją. Zeszyty Karmelitańskie, 2, 21-26.

Ordon, H. (1995). „A był im poddany...” (Łk 2,51). W: G. Witaszek (red.). Biblia w rodzinie (s. 1324). Lublin: Redakcja Wydawnictw KUL.

Papieska Rada ds. Krzewienia Nowej Ewangelizacji (2020). Dyrektorium o katechizacji. Kielce: Wydawnictwo „Jedność”.

PawlaczyK, B. (2013). Matka i dziecko w świetle Biblii. Poznań: Pallottinum.

Pikor, W. (2017). Stać się jak dziecko. Pastores, 1, 111-119.

Pinto, S. (2006). „Ascolta, figlio”. Autorità e antropologia dell 'insegnamento in Proverbi 1-9. Roma: Città Nuova.

Pотоскі, S. (1988). Proces formacji mądrościowej w ujęciu Prz 1-9. RTK, 33(1), 39-64.

Ratzinger, J. - Benedykt XVI (2012). Jezus z Nazaretu. Dzieciństwo (tł. W. Szymona). Kraków: Wydawnictwo „Znak”. 
Ravasi, G. (2002). Martini - moje trzy miasta. Przyjacielska rozmowa (tł. J. Zarzycka). Kraków: Wydawnictwo „Salwator”.

Rubinkiewicz, R. (1995). Rodzina jako środowisko wychowawcze. W: G. WitaszeK (red.), Biblia w rodzinie (s. 37-46). Lublin: Redakcja Wydawnictw KUL.

Signoretto, M. (2006). Metafora e didattica in Proverbi 1-9. Assisi: Cittadella.

Sikora, A.R. (1995). Rodzina w nowotestamentalnych „tablicach domowych”. W: G. WitASZEK (red.), Biblia w rodzinie (s. 47-67). Lublin: Redakcja Wydawnictw KUL.

Smalley, G. (2006). Klucz do serca twojego dziecka (tł. R. Jankowski). Lublin: Pojednanie.

SmoŁka, E. (2011). Personalizm (w pedagogice). W: EK, t. 15 (kol. 342-343). Lublin: Towarzystwo Naukowe KUL.

Strong, J. (2015). Grecko-polski słownik Stronga z lokalizacją słów greckich i kodami Popowskiego (tł. A. Czwojdrak). Warszawa: Oficyna Wydawnicza „Vocatio”.

Szwarc, U. (2000). ,[...] On twoim Ojcem [...]. Idea rodzicielstwa Jhwh w świetle Pwt 32. W: A.J. NowaK (red.), „Abba Ojcze!” (s. 103-116). Lublin: Redakcja Wydawnictw KUL.

ŚLIWERSKI, B. (2007). Pedagogika dziecka - studium pajdocentryzmu. Sopot: Wydawnictwo GWP.

TARnowski, J. (1982). Problem chrześcijańskiej pedagogiki egzystencjalnej. Warszawa: Wydawnictwo ATK.

TARnOwsKi, J. (1993). Jak wychowywać? Warszawa: Wydawnictwo ATK.

Tronina, A. (1995). Błogosławieństwo życia w rodzinie: Ps 128. W: G. WitaszeK (red.), Biblia w rodzinie (s. 87-98). Lublin: Redakcja Wydawnictw KUL.

Wojciechowska, K. (2015). Jezus jako pater familias. Relacja ojca i dziecka w czasach Jezusa i ich nowotestamentowa reinterpretacja. W: J.M. LIPNIAK (red.), Ekumeniczna wizja matżeństwa i rodziny. Szansa i życiowe problemy (s. 39-52). Wrocław: Papieski Wydział Teologiczny.

Wons, K. (2013). Dać się kochać jak dziecko (Mk 10,13-16; Mt 19,13-15; Łk 18,15-17), Salwator, $37(2), 24-25$.

Woyкe, J. (2000). Die neutestamentlichen Haustaffeln. Ein kritischer und konstruktiver Forschungsüberblick. Stuttgart: Verlag Katholisches Bibelwerk.

WronkA, S. (2013). Pozytywne i negatywne postawy dziecka w Ewangelii. ŚSHT, 46(2), 276-291.

\section{DZIECKO W PEDAGOGII BIBLIJNEJ}

\section{STRESZCZENIE}

Biblijna pedagogika dziecka ma swoje cele i zadania edukacyjne. Stawia dziecko w centrum odziaływań edukacyjnych, podkreślając jego godność i podmiotowość. Rodzice i wychowawcy cieszą się szczególnym autorytetem, stąd ze strony dzieci wymaga się szacunku (czci) i posłuszeństwa, podporządkowania i karności. Podobnie od rodziców wymaga się służebnej miłości i odpowiedzialności, kompetencji, uważnej troski i czułości. Pierwszym i podstawowym środowiskiem wychowawczym jest dom rodzinny, a inne ośrodki i instytucje edukacyjne - w oparciu o zasadę pomocniczości - mogą go wspierać $\mathrm{w}$ wypełnianiu tego fundamentalnego prawa i obowiązku. Pismo Święte nie jest podręcznikiem wychowania, gdyż przede wszystkim jest księgą natchnioną - księgą wiary. Biblia ma jednak swoją wartość edukacyjną, nie tylko ze względu na swoje walory literackie i historyczne, ale nade wszystko dlatego, że jest księgą Ducha Świętego, który „wszystkiego [nas] 
nauczy" (J 14,26). On też prowadzi do dojrzałości tych, którzy pragną żyć nowym życiem dzieci Bożych w Chrystusie, którego przyjmują z wiarą. Uważna lektura Pisma Świętego stanowi więc cenne źródło nauczania oraz duchową inspirację dla teologii wychowania (KO 24).

Słowa kluczowe: dziecko; pedagogia dziecka; Pismo Święte; pajdocentryzm.

\section{A CHILD IN BIBLICAL PEDAGOGY}

\section{SUMMARY}

The biblical pedagogy of a child has its own educational goals and tasks. It places the child in the center of educational impact, emphasizing its dignity and subjectivity. Parents and educators enjoy special authority, with regards to whom children are required to show respect (honor) and obedience, subjection and discipline. Similarly, parents are expected to have servant love and responsibility, competence, attentive care and tenderness. The first and basic educational environment is the family home, while other educational centers and institutions - based on the principle of subsidiarity - can support them in fulfilling this fundamental right and obligation. The Bible is not a textbook of education, because it is primarily an inspired book, a book of faith. Still, it does have an educational value, not only because of its literary and historical value, but above all because it is the book of the Holy Spirit who "will teach [us] all things" (John 14:26). He also leads to the maturity of those who wish to live the new life of God's children in Christ, whom they accept with faith. A careful reading of the Holy Bible is therefore a valuable source of teaching and a spiritual inspiration for theology of education (DV 24).

Keywords: child; child's pedagogy; Holy Bible; paidocentrism. 